\title{
Efektivitas Penyaluran KUR (Kredit Usaha Rakyat) Untuk Pengembangan UMKM
}

\author{
Suginam ${ }^{1, *}$, Sri Rahayu², Elvitrianim Purba ${ }^{3}$ \\ ${ }^{1}$ Prodi Manajemen Retail, Universitas Budi Darma, Medan, Indonesia \\ ${ }^{2}$ Prodi Akuntansi, Fakultas Ekonomi, Universitas Islam Sumatera Utara, Medan, Indonesia \\ ${ }^{3}$ Prodi Manajemen Informatika, AMIK STIEKOM Sumatera Utara, Rantauprapat, Indonesia \\ Email: 1, ${ }^{*}$ suginam.icha@gmail.com, ${ }^{2}$ sri.rahayu@fe.uisu.ac.id, ${ }^{3}$ elvitrianim40@gmail.com \\ Email Penulis Korespondensi: suginam.icha@gmail.com \\ Submitted: 15/08/2021; Accepted: 26/08/2021; Published: 30/08/2021
}

\begin{abstract}
Abstrak-Kredit Usaha Rakyat (KUR) merupakan program penjamin kredit, diaman program ini disalurkan kepada UMKM yang membutuhkan dana tambahan pinjaman untuk usaha mereka. Setelah program berjalan pihak lembaga penjamin memastikan program telah berjalan secara produktif atau efektif sehingga tercapainya target penyaluran program KUR. Tujuan dari penelitian ini adalah untuk menganalisis efektivitas penyaluran Kredit Usaha Rakyat (KUR) dan pengaruhnya terhadap peningkatan kinerja usaha mikro kecil. Jenis penelitian yang digunakan dalam penelitian ini adalah penelitian deskriptif. Penelitian deskriptif adalah penelitian yang berusaha mengdeskripsikan suatu gejala, peristiwa, kejadian yang terjadi. Penelitian deskriptif memusatkan perhatian pada masalah aktual sebagaimana adanya pada saat penelitian berlangsung. Melalui penelitian deskriptif, perusahaan berusaha mendeskripsikan peristiwa dan kejadian yang menjadi pusat perhatian tanpa perlakuan khusus terhadap peristiwa tersebut. Tahap terakhir dalam analisis data adalah penarikan kesimpulan dan verifikasi. Hasil penelitian ini menunjukan bahwa KUR dapat dikatakan efektif , karena telah memenuhi syarat yang ditetapkan.
\end{abstract}

\section{Kata Kunci: Efektivitas; Penyaluran; KUR; UMKM}

Abstract-People's Business Credit (KUR) is a credit guarantee program, where this program is channeled to MSMEs who need additional loan funds for their businesses. After the program runs, the guarantor institution ensures that the program has been running productively or effectively so that the target for the distribution of the KUR program is achieved. The purpose of this study was to analyze the effectiveness of the distribution of People's Business Credit (KUR) and its effect on improving the performance of micro and small enterprises. The type of research used in this research is descriptive research. Descriptive research is research that seeks to describe a symptom, event, event that occurs. Descriptive research focuses on the actual problem as it was at the time the research took place. Through descriptive research, the company tries to describe events and events that are the center of attention without special treatment for these events. The last stage in data analysis is drawing conclusions and verification. The results of this study indicate that KUR can be said to be effective, because it has met the specified requirements.

Keywords: Effectiveness; Distribution; KUR; UMKM

\section{PENDAHULUAN}

Pada masa sekarang ini Indonesia termasuk kedalam negara miskin dan berkembang yang masih tertinggal dari banyak hal. Ketertinggalan tersebut baik dalam bentuk pemerintaahan, tata kelola, kemakmuran ataupun segi ekonomi. Ketertinggalan dan permasalahan ekonomi merupakan permasalahan utama yang harus segera dituntaskan. Hal tersebut didasari dengan bahwa perekonomian merupakan dasar dari keberlangsungannya bagi negara berkembang.

Aspek pada saat ini yang dijalankan oleh masyarakat guna meningkatkan sektor ekonomi dan meningkatkan kualitas hidup agar lebih baik yaitu dengan membangun usaha sendiri yang bersifat pribadi, dimana usaha tersebut masuk dalam beberapa golongan. Salah satu golongan tersebut adalah Usaha Mikro, Kecil dan Menengah (UMKM). Sektor Usaha Mikro, Kecil dan Menengah (UMKM) meruapakan salah satu kegiatan masyarakat yang memiliki dampak juga efek yang cukup besar untuk menolong tumbung kembangnya perekonomian bagi negara berkembang. Dengan adanya Usaha Kecil, Mikro dan Menangah (UMKM) dapat menyerap tenaga kerja serta menyumbangkan devisa bagi negara.

Bagi Usaha Mikro, Kecil dan Menengah (UMKM) faktor yang dapat meningkatkan pendapatan adalah besarnya modal usaha dari Usaha Mikro, Kecil dan Menengah (UMKM) tersebut(Antara \& Luh Putu Aswitari, 2016). Modal usaha merupakan hal dasar dan aspek penting bagi pelaku usaha untuk menjalankan atau membangun sebuah Usaha Mikro, Kecil dan Menengah (UMKM)(Anggraeni et al., 2013). Modal merupakan dana yang dikeluarkan untuk mendapatkan barang juga jasa yang dihasilkan oleh seseorang. Tidak adanya modal usaha bagi Usaha Mikro, Kecil dan Menengah (UMKM) tentu tidak akan bisa menyelesaikan atau menghasilkan sebuah produk dalam bentuk barang ataupun jasa. Sehingga tanpa modal usaha Usaha Mikro, Kecil dan Menengah (UMKM) tidak akan bisa mendapatkan pemasukan, hal ini dikarenakan Usaha Mikro, Kecil dan Menengah (UMKM) juga tidak akan bisa menghasilkan barang atau jasa yang akan ditawarkan pada konsumen atau pembeli. Modal usaha bagi Usaha Mikro, Kecil dan Menengah (UMKM) tidak hanya berasal dari pemiliki Usaha Mikro, Kecil dan Menengah (UMKM) tersebut, tetapi juga bisa berasala dari pihak pihak lainnya(Anggraeni et al., 2013).

Peranan Usaha Mikro, Kecil dan Menengah (UMKM) tersebut saat ini sangatlah penting, dikarenakan Usaha Mikro, Kecil dan Menengah (UMKM) bukan saja sebagai tempat mata pencaharian bagi pelaku usaha ataupun banyak orang tetapi juga sebagai tempat ataupun penyedia lapangan pekerjaan bagi masyarakat yang berpendidikan rendah tetapi memiliki kemampuan skill dan keterampilan(SUGIANTI, 2019). Menurut (Wijayanto, 2013) mengemukakan bahwa 
usaha kecil kebanyakan tidak memiliki stategi atau kekurangan ahli strategi. Hal tersebut yang menyebabkan Usaha Mikro, Kecil dan Menengah (UMKM) sangat sulit untuk berkembang.

Kinerja dari Usaha Mikro, Kecil dan Menengah (UMKM) tersebut sangat bergantung terhadap dua faktor utama yang mendasar yaitu faktor eksternal berupa kebijakan dari pemerintah, aspek sosial dan budaya, dana ekonomi dan juga peranan dari lembaga terkait disekitar pelaku Usaha Mikro, Kecil dan Menengah (UMKM) seperti pemerintah, perguruan tinggi, perusahaan swasta juga lembaga sosial masyarakat. Selain itu, faktor lingkungan bisnis internal juga memiliki dampak kinerja bagi Usaha Mikro, Kecil dan Menengah (UMKM) tersebut. Sehingga diperlukan sebuah usaha ataupun tindakan guna mengambangkan, memajukan dan memperluas Usaha Mikro, Kecil dan Menengah (UMKM) bagi perekonomian masal nasional. Dengan cara melakukan pembinaan yang berdasarkan pada keterbatasan pengetahuan, keterbatasan informasi dan keterbatasan dana yang digunakan sebagai modal usaha bagi Usaha Mikro, Kecil dan Menengah (UMKM)(Siagian et al., 2019).

Dari beberapa permasalahan yang dihadapi oleh Usaha Mikro, Kecil dan Menengah (UMKM) tersebut pemerinta Indonesia melalui inpres Nomor 6 tanggal 8 Juni 2007 yang berisi tentang keibajakn - kebijakan dalam pengembangan sektor Riil juga pemberdayaan Usaha Mikro, Kecil dan Menengah (UMKM) yang disertai dengan kesepahaman bersama antara Departemen Teknis, perbankan juga perusahaan penjamin kredit ataupun pembiayaan kepada Usaha Mikro, Kecil dan Menengah (UMKM). Pada tanggal 05 November 2007, dimana dengan presiden Indonesia pada waktu itu melakukan peresmian kredit bagi Usaha Mikro, Kecil dan Menengah (UMKM) dengan penjamin nama kredit adalah Kredit Usaha Rakyat (KUR).

Peresmian tersebut juga didukung dengan inpres Nomor 5 tahun 2008 tentang fokus pada program ekonomi 20082009 untuk melakukan penjaminan ataupun percepatan pelaksanaan Kredit Usaha Rakyat (KUR) tersebut. Beberapa pembahasan diantaranya dengan penyelesaian terhadap kredit bermasalah bagi Usaha Mikro, Kecil dan Menengah (UMKM) juga pemberitahuan kredit Usaha Mikro, Kecil dan Menengah (UMKM) dengan nominal sampai dengan Rp. 500.000.000,-. Inpres tersebut juga didukung oleh peraturan menteri keuangan No. 135/pmk.05/2008 tentang perubahan atas peraturan menteri keuangan No. 1259/pmk.05/ 2011 tentang fasilitas penjamin Kredit Usaha Rakyat (KUR).

Untuk mengetahui Kredit Usaha Rakyat (KUR) tersebut berjalan sesuai dengan harapan atau tidak sesuai dengan tahapan - tahapan proses yang telah ditentukan, dilihat dari pencapaian target yang sudah ditentukan oleh pemerintah untuk membantu bagi pelaku Usaha Mikro, Kecil dan Menengah (UMKM) ataupun masyarakat pemerintah bekerja sama dengan badan usaha milik pemerintah agar mudah untuk melakukan kontrol terhadap hasil yang didapatkan.

Pemerintah sudah mencangankan Kredit Usaha Rakyat (KUR) tahun 2007 sebagai bentuk respon atas instruksi presiden (inpres) No. 6 tahun 2007 tentang kebijakan terhadap percepatan pengembangan sektor Riil juga pemberdayaan Usaha Mikro, Kecil dan Menengah (UMKM). Inpres tersebut dijalankan dengan ditandai oleh ditanda tanganinya sebuah nota kesepahaman bersama (Memorandum of Understanding) antara pemerintah, lembaga penjamin juga perbankan terhadap penjamin kredit pembiyaan Usaha Mikro, Kecil dan Menengah (UMKM) dan koperasi atau lebih sering dikenal dengan Kredit Usaha Rakyat (KUR).

Program Kredit Usaha Rakyat (KUR) ini disalurkan bagi pelaku Usaha Mikro, Kecil dan Menengah (UMKM) yang kiranya memerlukan dana modal tambahan bagi usaha yang sedang dijalankan. Ketika program berjalan pihak penyalur Kredit Usaha Rakyat (KUR) akan memastikan apakah program tersebut sudah berjalan secara produktif atau efektif sehingga terpenuhinya target yang telah ditentukan pada program Kredit Usaha Rakyat (KUR) tersebut.

Aspek yang digunakan untuk mengukur efektiftas terhadap penyaluran Kredit Usaha Rakyat (KUR) tersebut untuk peningkatan kinerja Usaha Mikro, Kecil dan Menengah (UMKM) dapat dilihat dari 4 prosedur berikut :

1. Prosedur ketepatan sasaran, yaitu melalui sejauh mana pelanggan dari program Kredit Usaha Rakyat (KUR) tersebut tepat dengan sasaran yang sudah ditentukan sebelumnya. Sasaran dari program Kredit Usaha Rakyat (KUR) adalah para pelaku Usaha Mikro, Kecil dan Menengah (UMKM) yang kekurangan terhadap modal usaha untuk memulai atau mengembangkan usaha yang dijalankannya.

2. Prosedur ketepatan waktu, yaitu dengan adanya batasan waktu yang sudah ditentukan dalam pemberian Kredit Usahar Rakyat (KUR) terhadap pemohon dalam menentukan bersarnya jumlah angka kredit yang diajukan oleh para pelaku Usaha Mikro, Kecil dan Menengah (UMKM).

3. Prosedur ketepatan jumlah, yakni berupa ketepatan jumlah yang nantinya diterima oleh para pelaku Usaha Mikro, Kecil dan Menengah (UMKM) dari lembaga penjamin kredit berdasarkan dengan pengajuan angka kredit sebelumnya. Dalam proses pemberian kredit Usaha Mikro, Kecil dan Menengah (UMKM), pemohon terlebih dahulu mengajukan permohonan angka kredit yang akan diperolah dan jangka waktu penyelesaian Kredit Usaha Rakyat (KUR) tersebut.

4. Prosedur ketepatan kredit, berupa ketentuan yang sudah disepakati antara debitur juga kreditur tentang segala hal yang berkaitan dengan Kredit Usaha Rakyat (KUR).

Pada penelitian ini akan melakukan sebuah penelitian untuk mengukur apakah program Kredit Usaha Rakyat (KUR) sudah efektif atau belum sesuai dengan indikator dari tujuan program. Salah satu faktor yang dapat meningkatkan pendapatan ialah besarnya modal usaha(Antara \& Luh Putu Aswitari, 2016). Dalam memulai sebuah usaha, salah satu yang penting yang dibutuhkan adalah modal. Modal adalah dana yang harus dikeluarkan untuk menghasilkan barang atau jasa yang dihasilkan seseorang. Tanpa adanya modal usaha seseorang belum bisa menyelesaikan pembuatan barang dan jasa sesuai permintaan. Jadi tanpa modal usaha seseorang tidak akan mendapatkan pembeli karena tidak ada barang dan jasa yang dihasilkan. Untuk menaikan hasil produksi barang dan jasa tidak cukup dengan menggunakan modal sendiri(Anggraeni et al., 2013). 
Menurut (Anggraini \& Nasution, 2013)bahwa semakin besar jumlah modal KUR yang diperoleh oleh UMKM maka semakin tinggi tingkat pendapatan yang akan diperoleh UMKM. begitu juga sebaliknya. Namun disisi lain menurut penelitian (Lastina \& Budhi, 2018) menyatakan bahwa semakin baik modal pinjaman KUR yang diambil oleh UMKM, maka penghasilan UMKM juga akan mengalami peningkatan.

Indikator efektivitas dalam penyaluran kredit meliputi berhasil atau tidaknya seseorang atau suatu organisasi untuk mencapai suatu tujuan dalam penyaluran kredit, adanya perkembangkan dan pertumbuhan yang dialami seseorang ketika adanya penyaluran kredit, dan adanya perbedaan positif secara signifikan antara apa yang diharapkan dengan apa yang terjadi(sebelum atau sesudah) dalam penyaluran kredit. KUR yang disalurkan BRI di Medan Perjuangan diharapkan akan mampu mengatasi masalah UMKM. Menurut (HAOJAHAN, 2014) ada kasus lain yang menjadi sorotan adalah adanya sebagian pelaku usaha yang meminjam bantuan KUR tersebut, tetapi tidak menggunakan bantuan yang tersebut sebagai modal usaha, tetapi untuk hal - hal lain yang tidak ada kaitanya dengan usaha Untuk dijalani, sehingga membuat pelaku usaha tersebut sulit dalam melakukan kewajiban kepada bank pelaksana peminjam modal tersebut.

Mengembangkan UMKM di Indonesia pemerintah dan beberapa lembaga keuangan non bank maupun lembaga perbankan telah membantu para pelaku sektor UMKM dalam mengembangkan usahanya melalui pemberian kredit ataupun pinjaman lunak kepada para pelaku usaha mikro, kecil, dan menengah(UMKM). Salah satu kontribusi pemerintah dalam mengembangkan UMKM, yaitu melalui pemberian kredit usaha rakyat(KUR). Pemberian KUR dimulai dengan adanya keputusan sidang kabinet terbatas yang diselenggrakan pada tanggal 9 Maret 2007 yang dilaksanakan dikantor Kementrian Negara Koperasi dan Usaha Kecil Menengah(UKM) dengan dipimpin oleh Bapak Presiden RI. Salah satu agenda pembicaraan keputusannya antara lain, bahwa dalam rangka pengembangan sektor UMKM dan koperasi, pemerintah akan mendorong penigkatan akses pelaku UMKM dan koperasi kepada kredit pembiayaan dari perbankan melalui peningkatan kapasitas perusahaan penjamin.

Atas diajukannya permohonan peminjaman kredit tanpa jaminan tersebut, tentu saja harus mengikuti berbagai prosedur yang ditetapkan oleh bank yang bersangkutan. Selain itu, pemohon harus mengetahui hak dan kewajiban apa yang akan timbul dari masing - masing pihak yaitu debitur dan kreditur dengan adanya perjanjian Kredit Usaha Rakyat (KUR) tanpa jaminan ini, mengingat segala sesuatu dapat dapat saja timbul menjadi suatu permasalahan apabila tidak ada pengetahuan yang cukup tentang Kredit Usaha Rakyat (KUR) tanpa jaminan ini,selain memberikan kredit usaha rakyat pemerintah dalam rangka pemberdayaan usaha mikro hingga saat ini juga pemerintah telah melakukan langkah langkah stategis sebagai berikut, yaitu:

a. Menciptakan iklim usaha yang kondusif dan menyediakan lingkungan yang mampu mendorong pengembangan Usaha Mikro Kecil dan M(UMKM) secara sistematik, mandiri dan berkelanjutan.

b. Menciptakan sistem penjaminan (financial guarantee ) untuk mendukung kegiatan ekonomi produktif usaha mikro.

c. Menyediakan bantuan teknis dan pendampingan (technical assistance and facilitation secara manajerial guna meningkatkan"status usaha" usaha mikro agar fleaksible dan bankable dalam jangka panjang.

d. Penataan dan penguatan kelembagaan keuangan mikro untuk memperluas jangkauan pelayanan keuangan kepada usaha mikro secara cepat, tepat, mudah dan sistematis.

Pemerintah telah menyusun beberapa kebijakan kredit. Seperti, adanya nota kesepahaman (MoU) antara Komite Penanggulangan Kemiskinan(KPK) dengan bank indonesia mengenai penanggulangan kemiskinan melalui pemberdayaan UMKM. kerjasama ini dimaksudkan untuk menciptakan iklim yang kondusif bagi usaha mikro, kecil dan menengah (UMKM). kesimpulannya adalah dengan diberikannya Kredit Usaha Rakyat (KUR) oleh pemerintah dan lembaga perbankan ataupun lembaga keuangan non bank dapat mengurangi beberapa kendala yang sering dialami para pelaku Usaha, Mikro, dan Menengah (UMKM) yaitu berupa agunan (jaminan) yang biasanya diminta oleh bank sebelum memberikan kredit kepada pelaku sector Usaha mikro, kecil, dan menengah (UMKM). Dengan adanya kelebihan dari kredit usaha rakyat (KUR), yaitu berupa pinjaman tanpa agunan (jaminan), para pelaku Usaha Mikro, Kecil, dan Menengah (UMKM) dapat mengembangkan usaha menjadi lebih besar dengan menggunakan dana pinjaman dari program Kredit Usaha Rakyat (KUR) yang pada akhirnya berdampak kepada meningkatnya kesejahteraan rakyat karena berkurangnya penggangguran yang telah diserap oleh sector UMKM.

\section{METODOLOGI PENELITIAN}

\subsection{Kredit}

Menurut (Jusuf, 2014) pengertian kredit adalah kemampuan untuk melaksanakan sesuatu pembelian atau mengadakan suatu pinjaman dengan suatu janji, pembayaran akan dilaksanakan pada jangka waktu yang telah disepakati.

Adapun pengertian kredit yang lain adalah penyediaan uang atau tagihan yang dapat dipersamakan dengan itu berdasarkan persetujuan atau kesepakatan pinjam meminjam antara pihak bank dengan pihak lain yang mewajibkan pihak peminjam untuk melaksanakan dengan jumlah harga sebagai imbalan. Dalam praktek sehari - hari pinjaman kredit dinyatakan dalam bentuk perjanjian tertulis baik dibawah tangan maupun secara materil. Dan sebagai jaminan pengaman, pihak peminjam akan memenuhi kewajiban dan menyerahkan jaminan baik bersifat kebendaan maupun bukan kebendaan.

Dalam kehidupan sehari - hari, kata kredit merupakan perkataan yang tidak asing lagi bagi masyarakat. Kredit tidak saja dikenal oleh masyarakat di perkotaan tetapi sampai di pedesaan pun kredit sudah sangat populer. Istilah kredit berasal dari bahasa Yunani yaitu credere yang berarti kepercayaan, maksudnya adalah apabila seseorang memperoleh kredit maka berarti mereka memperoleh kepercayaan. Sedangkan bagi dipinjamkan pasti kembali. Pengertian kredit 
menurut UU Perbankan No. 10 tahun 1998 adalah "penyediaan uang atau tagihan yang dapat dipersamakan dengan itu, berdasarkan persetujuan atau kesepakatan pinjam meminjam antara bank dengan pihak lain yang mewajibkan pihak peminjam melunasi uangnya setelah jangka waktu tertentu dengan pemberian bunga".

Dalam pengertian di atas dapat dijelaskan bahwa kredit dapat berupa uang atau tagihan yang nilainya diukur dengan uang, misalnya bank membiayai kredit untuk pembelian rumah atau mobil. Kemudian adanya kesepakatan antara bank (kreditur) dengan nasabah penerima kredit (debitur), dengan perjanjian kredit tercakup hak dan kewajiban masing - masing pihak termasuk jangka waktu, bunga yang ditetapkan bersama serta masalah sangsi apabila si debitur ingkar janji terhadap perjanjian yang telah dibuat.

\subsection{Kredit Usaha Rakyat (KUR)}

Kredit berasal dari kata credere yang berarti kepercayaan maksudnya adalah apabila seseorang memperoleh kredit maka berarti mereka memperoleh kepercayaan.Sedangkan bagi si pemberi kredit artinya memberikan kepercayaan kepada seseorang bahwa uang yang dipinjamkan pasti kembali. Pengertian "kredit" merupakan Undang - Undang Perbankan Nomor 10 tahun 1998 adalah "penyediaan uang atau tagihan yang dapat dipersamakan dengan itu, berdasarkan persetujuan atau kesepakatan pinjam meminjam antara bank dengan pihak lain yang mewajibkan pihak peminjam melunasi utangnya setelah jangka waktu tertentu dengan pemberian bunga"(Fransiska, 2016).

Transaksi kredit dapat terjadi atau timbul karena ada suatu pihak yang meminjam uang atau barang kepada pihak lainnya yang dapat menimbulkan tagihan bagi kreditur. Hal lain yang dapat menimbulkan transaksi kredit adalah kegiatan jual beli dimana pembayarannya akan ditangguhkan dalam jangka waktu tertentu baik sebagian ataupun seluruhan. Aktivitas kredit diatas secara teknis akan mendatangkan piutang bagi kreditur dan mendatangkan uang bagi debitur.

Pada umumnya, kredit merupakan program kerja dari sebuah bank yang kegiatannya adalah meminjamkan uang kepada orang - orang yang membutuhkan baik itu nasabah mereka ataupun tidak dengan menggunakan berbagai jaminan sesuai dengan ketentuan yang berlaku. Pengertian kredit menurut Undang - Undang No. 7 Tahun 1992 tentang perbankan adalah penyediaan uang atau tagihan yang dapat dipersamakan dengan itu, berdasarkan persetujuan kesepakatan pinjam - meminjam antara bank dengan pihak lain yang mewajibkan pihak meminjam untuk melunasi hutangnya setelah jangka waktu tertentu dengan jumlah bunga, imbalan atau pembagian hasil keuntungan. Program pemberian kredit yang banyak dilakukan oleh bank - bank memiliki tujuan yang hampir sama yaitu untuk memberi kesepakatan kepada orang - orang atau masyarakat untuk membuka atau merintis pekerjaan sendiri yang berguna untuk memperbaiki keadaan ekonomi mereka. Pemberian kredit ini terbagi atas pemberian kredit oleh bank itu sendiri dan ada yang bekerjasama dengan pemerintah.

Kredit Usaha Rakyat (KUR) adalah salah satu jenis kredit yang terbentuk dari hasil kerjasama dengan pemerintah. Kredit ini diberikan melalui bank sebagai kreditur atau penyedia dana untuk masyarakat yang ingin membangun usaha sendiri

Kredit Usaha Rakyat (KUR) ini adalah kredit yang ditujukan bagi peminjam yang ingin merintis usaha sendiri tetapi masih dengan skala mikro, kecil dan menengah. Pemerintah sendiri memiliki komitmen untuk membantu membangun Usaha Mikro Kecil dan Menengah (UMKM) serta meningkatkan kesejahteraan masyarakat. Salah satu bentuk komitmen itu adalah dengan dibukanya kredit untuk modal usaha bagi Usaha Mikro dan Kecil (UMK) dan koperasi yang disebut dengan Kredit Usaha Rakyat (KUR) ini merupakan alternatif bagi Usaha Mikro, Kecil dan Koperasi untuk mendapatkan modal usaha. Kendala yang seringkali dihadapi oleh pengusaha Mikro, Kecil dan Koperasi adalah masalah permodalan dihadapi oleh pengusaha Mikro, Kecil dan Menengah adalah masalah permodalan di dalam mengembangkan usahanya.

KUR sendiri pertama kali diluncurkan oleh Presiden Susilo Bambang Yudhoyono pada tanggal 5 November 2007.Tujuan diluncurkannya KUR adalah untuk mempercepat pengembangan sektor riil dan pemberdayaan UMKM, untuk meningkatkan akses pembiayaan kepada UMKM dan Koperasi dan untuk penanggulangan kemiskinan dan perluasan kesempatan kerja.Pada dasarnya, KUR merupakan modal kerja dan kredit investasi yang disediakan secara khusus untuk unit usaha produktif melalui program penjaminan kredit. Perseorangan, kelompok atau koperasi dapat mengakses program ini dengan kredit maksimum $\mathrm{Rp} 500.000 .000,-$.

Sumber dananya adalah bank yang ditunjuk dengan tingkat bunga maksimum 16 persen per tahun. Persentase kredit yang dijamin adalah 70 persen dari alokasi total kredit yang disediakan oleh bank tersebut. Masa pinjam kredit untuk modal kerja maksimum 3 tahun dan 5 tahun untuk investasi. Secara nasional penyaluran KUR banyak diarahkan ke sektor perdagangan, restoran dan hotel yang mencapai 55\% dari total penyaluran KUR diikuti dengan penyaluran ke sektor pertanian sebesar 27\% dan sektor - sektor lain sebesar 9\%.

\subsection{Pengukuran Efektivitas Kredit Usaha Rakyat (KUR)}

Efektivitas merupakan unsur pokok untuk mencapai tujuan atau sasaran yang telah ditentukan di dalam setiap organisasi, kegiatan ataupun program. Disebut efektif apabila tercapai tujuan ataupun sasaran seperti yang telah ditentukan. Menurut (Wahyuni, 2016), efektivitas adalah tercapainya sasaran yang telah disepakati bersama. Pengukuran efektivitas secara umum dan yang paling menonjol adalah:

a. Keberhasilan program

b. Keberhasilan sasaran

c. Kepuasan terhadap program

d. Tingkat input dan output. 
Dengan demikian efektivitas diartikan sebagai suatu pengukuran akan tercapainya tujuan yang telah direncanakan sebelumnya. Efektivitas (effectiveness) yang didefinisikan secara abstrak sebagai tingkat pencapaian tujuan, diukur dengan rumus hasil dibagi dengan tujuan.Tujuan yang bermula pada visi yang bersifat abstrak itu dapat dideduksi sampai menjadi kongkrit, yaitu sasaran atau stategi.Maka seseorangan dikatakan efektif apabila menimbulkan atau mempunyai maksud sebagaimana yang dikehendaki.

Dari semua penjelasan tersebut dapat ditarik kesimpulan bahwa suatu hal dapat dikatakan efektif apabila hal tersebut sesuai dengan yang dikehendaki, artinya pencapaian hal yang dimaksud merupakan pencapaian tujuan dilakukannya tindakan - tindakan untuk mencapai hal tersebut. Efektivitas dapat diartikan sebagai suatu proses pencapaian suatu tujuan yang telah ditetapkan sebelumnya. Suatu usaha atau kegiatan dapat dikatakan efektif apabila usaha atau kegiatan tersebut telah mencapai tujuannya. Apabila tujuan yang dimaksud adalah tujuan suatu instansi maka proses pencapaian tujuan tersebut merupakan keberhasilan dalam melaksanakan program atau kegiatan menurut wewenang, tugas dan fungsi instansi tersebut.

\subsection{Usaha Mikro dan Kecil}

Usaha Mikro sebagaimana dimaksud menurut Keputusan Menteri Keuangan No. 40/KMK.06/2003 tanggal 29 Januari 2003, yaitu usaha produktif milik keluarga atau perorangan Warga Negara Indonesia dan memiliki hasil penjualan paling banyak Rp. 100.000.000,00 (seratus juta rupiah) per tahun. Usaha mikro dapat mengajukan kredit kepada bank maksimal Rp. 50.000.000,00(INDONESIA, 2003).

Sedangkan Usaha Kecil adalah suatu produktif yang berskala kecil dan memiliki kekayaan bersih paling banyak Rp.200.000.000,00 (dua ratus juta rupiah) tidak termasuk tanah dan bangunan tempat usaha atau memiliki hasil penjualan paling banyak Rp.1 milyar pertahun serta dapat menerima kredit dari Bank di atas Rp. 50 juta sampai Rp. 500 juta.

Upaya pemerintah dalam pengembangan usaha mikro kecil dan menengah idealnya dapat dilakukan dengan baik, akan tetapi faktanya upaya pemerintah dalam pengembangan usaha mikro kecil dan menegah (UMKM) masih belum mencapai ideal. Penelitian ini bertujuan untuk mengetahui bagaimana peranan pemerintah dalam pengembangan usaha mikro kecil dan menengah (UMKM) Dikecamatan Si Pirok. Pendekatan penelitian ini adalah kualitatif deskriftif .deskriptif yaitu pendekatan yang dilakukan untuk menganalisi data dengan cara menyajikan, mendeskripsikan, atau mengambarkan data yang telah terkumpul sebagaimana adanya tanpa bermaksud membuat yang berlaku untuk umum, dan menginterprestasi kan hasil penelitian. Berdasarkan hasil penelitian ini penulis, maka upaya pemerintah dalam pengembangan usaha mikro kecil dan menengah (UMKM) di Kabupaten Tapanuli Selatan(studi kasus Sipirok) ada enam yaitu memaksimalkan potensi yang ada dalam masyarakat, kemudian akses terhadap pasar, bekerjasama dengan bank baik negeri maupun swasta, kemudahan dalam mendapatkan legalitas formal, penjaminan terhadap perlindungan dan kelangsungan usaha, memanfaatkan teknologi untuk pengembangan UMKM. peranan utama yang mempengaruhi pengembangan usaha mikro kecil dan menengah (UMKM) di Kabupaten Tapanuli Selatan adalah memaksimalkan potensi yang ada dalam masyarakat(Ramayanti, 2018).

\subsection{Penelitian Terkait}

Penelitian yang dilakukan oleh peneliti sebelumnya, dengan tempat dan waktu penelitian yang berbeda, yang dapat dilihat pada tabel di bawah ini:

Tabel 1. Penelitian Terdahulu

\begin{tabular}{|c|c|c|c|}
\hline Nama & Judul & Sumber & Hasil penelitian \\
\hline $\begin{array}{l}\text { (Putra \& Saskara, } \\
\text { 2013) }\end{array}$ & $\begin{array}{l}\text { Efektivitas dan dampak } \\
\text { program bantuan kredit } \\
\text { usaha rakyat (KUR) } \\
\text { terhadap pendapatan dan } \\
\text { kesempatan kerja usaha } \\
\text { mikro kecil dan menengah } \\
\text { (UMKM) di Kota Denpasar }\end{array}$ & $\begin{array}{l}\text { Dikota Denpasar. } \\
\text { E- Jurnal } \\
\text { Ekonomi } \\
\text { Pembangunan } \\
\text { Universitas Udayana. } \\
\text { Vol. 2, No. 10, } \\
\text { Oktober } 2013\end{array}$ & $\begin{array}{l}\text { Hasil penelitian menunjukan } \\
\text { bahwa efektivitas program kredit } \\
\text { usaha rakyat (KUR) terdapat } \\
\text { bebarapa kekurangan seperti pada } \\
\text { indikator tujuan program, yaitu } \\
\text { tidak tepatnya sasaran program. }\end{array}$ \\
\hline (Erlina, 2014) & $\begin{array}{l}\text { Analisis } \\
\text { Pemberian Kredit Usaha } \\
\text { Rakyat (KUR) Terhadap } \\
\text { Kinerja Usaha Kecil. }\end{array}$ & $\begin{array}{l}\text { PT. Bank } \\
\text { Rakyat Indonesia } \\
\text { (Persero) Tbk Cabang } \\
\text { A. Yani Makassar }\end{array}$ & 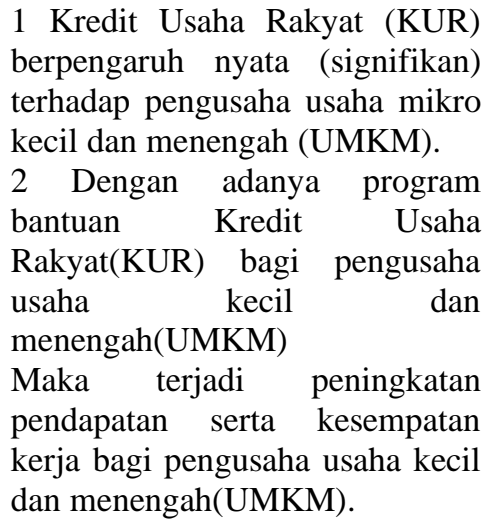 \\
\hline
\end{tabular}




\begin{tabular}{lllll}
\hline \multicolumn{1}{c}{ Nama } & \multicolumn{2}{c}{ Judul } & \multicolumn{1}{c}{ Sumber } & \multicolumn{1}{c}{ Hasil penelitian } \\
\hline (Widyaresti & $\&$ & Analisis Peran BRI Dalam & Fakultas Ekonomi & Hasil penelitian ini menunjukan \\
Setiawan, 2012) & Pemberian Kredit Usaha dan Bisnis, 2012 & bahwa pemberian kredit usaha \\
& Rakyat Bagi Pengusaha di Kecamatan & $\begin{array}{l}\text { rakyat(KUR) dapat dimanfaatkan } \\
\text { Mikro Kecil dan Ngawen Kabupaten untuk mengembangkan usaha }\end{array}$ \\
& Menengah(UMKM). & Klaten. & mikro kecil dan menengah. \\
& & & Setelah mendapatkan pinjaman \\
& & & KUR dari BRI variabel modal, \\
& & & produksi, omzet penjualan dan \\
& & & keuntungan meningkat rata - rata \\
& & & lebih dari 100 persen.
\end{tabular}

\subsection{Pendekatan Penelitian}

Penelitian ini merupakan penelitian yang menggunakan pendekatan kualitatif. Pendekatan kualitatif adalah suatu proses penelitian dan pemahaman yang berdasarkan pada metodologi yang menyelidiki suatu fenomena sosial dalam masalah manusia. Pada pendekatan ini, peneliti menekankan sifat realitas yang terbangun secara sosial, hubungan erat antara peneliti dan subjek yang diteliti. Jenis penelitian yang digunakan dalam penelitian ini adalah penelitian deskriptif. Metode yang digunakan dalam penelitian ini adalah metode deskriptif kualitatif. Penelitian deskriptif adalah penelitian yang berusaha mendeskripsikan suatu gejala, peristiwa, kejadian yang terjadi. Penelitian deskriptif memusatkan perhatian pada masalah aktual sebagaimana adanya pada saat penelitian berlangsung. Melalui penelitian deskriptif, peneliti berusaha mendeskripsikan peristiwa dan kejadian yang menjadi pusat perhatian tanpa memberikan perlakuan khusus terhadap peristiwa tersebut.

\subsection{Teknik Pengumpulan Data dan Analisa Data}

Adapun teknik pengumpulan data di lapangan ini dilakukan dengan cara:

1. Observasi (pengamatan), yaitu mengadakan pengamatan secara langsung terhadap situasi perkembangan perusahaan yang diteliti dan prosedur yang ada pada perusahaan pada saat dilakukan riset.

2. Wawancara (interview), yaitu mengadakan tanya jawab (fase to fase) dengan pihak perusahaan yang mempunyai wewenang untuk memberikan informasi / data yang dibutuhkan dalam penelitian ini.

Analisis data dalam penelitian kualitatif dilakukan saat proses dan setelah selesainya pengumpulan data. Pada saat melakukan wawancara, peneliti sudah melakukan analisis terhadap jawaban dari informan atau narasumber. Bila jawaban tersebut setelah dianalisis belum memuaskan maka peneliti akan melanjutkan pertanyaannya lagi sampai data yang diperoleh dianggap kredibel.

Adapun aktivitas dalam teknik analisa data pada kualitatif adalah sebagai berikut:

\section{Reduksi data}

Reduksi data dapat diartikan sebagai proses penelitian, pemusatan perhatian pada penyederhanaan, pengabstrakan, dan transformasi data kasar yang muncul dari catatan - catatan tertulis dari lapangan.

2. Penyajian data

Setelah data direduksi, maka langkah selanjutnya adalah penyajian data. Dalam penelitian kualitatif, penyajian data bisa dilakukan dalam bentuk uraian singkat, bagan, hubungan antara kategori, dan sejenisnya. Yang sering digunakan untuk menyajikan data dalam penelitian kualitatif adalah teks yang bersifat naratif.

3. Pemeriksaaan kesimpulan dan vertifikasi

Tahap terakhir dalam analisis data kualitatif adalah penarikan kesimpulan dan verifikasi. Beberapa cara yang digunakan dalam proses ini adalah dengan melakukan pencatatan pola - pola dan tema yang sama, pengelompokan, dan pencarian kasus - kasus negatif (kasus khas, berbeda, mungkin pula menyimpang dari kebiasaan yang ada dimasyarakat).

\section{HASIL DAN PEMBAHASAN}

Efektivitas adalah adanya kesinambungan tujuan yang telah ditetapkan oleh pelaksana dengan nasabah,dapat bermanfaat bagi pengusaha - pengusaha mikro dalam mengembangkan usahanya yang ditandai dengan meningkatnya volume penjualan dan adanya timbal balik yang diberikan nasabah kepada bank pelaksana berupa pembayaran angsuran tepat waktu.

\subsection{Pembahasan}

Dari pemaparan hasil penelitian diatas, maka peneliti akan membahas mengenai tentang perbedaan pemberian kredit dengan yang sesungguhnya. Kredit yang akan diberikan berdasarkan kepada kepercayaan. Sehingga sama dengan demikian, pemberian kredit merupakan pemberian kepercayaan. Ini berarti bahwa bank akan memberikan kredit kalau ia benar - benar yakin bahwa si penerima kredit akan mengembalikan pinjaman yang diterimanya sesuai dengan jangka waktu dan syarat - syarat yang telah disetujui oleh kedua belah pihak (Kasmir, 2014). 
Keefektivitsan program dapat dijalankan dengan kemampuan operasional serta tujuan yang telah ditetapkan sebelumnya. keberhasilan program KUR Mikro dapat ditinjau dari proses dan mekanisme suatu kegiatan yang dilakukan dilapangan. Hal yang sama diungkapkan oleh Jones dan Arif Rohman (2015: 101-102) menyatakan bahwa program merupakan salah satu komponen dalam suatu kebijakan. Dimana dengan adanya program merupakan sebuah upaya utuk mencapai tujuan. Sama halnya dengan program KUR Mikro yang meupakan sebuah program dari pemerintah memenuhi kebutuhan masyarakat.

Pemaparan teori tersebut sejalan dengan penelitian yang dilakukan oleh Aulia (2017), dimana program Kredit Usaha Rakyat (KUR) Mikro berjalan secara efektif dan menunjukan program KUR berpengaruh positif terhadap kinerja UMKM. Dapat dilihat dari lima aspek yaitu aspek ketepatan sasaran program, aspek ketepatan waktu, aspek ketepatan jumlah kredit, aspek ketepatan beban dan aspek ketepatan prosedur.

Menurut bank Indonesia pasal 1 Undang - Undang No. 10 tahun 1998 pemberian merupakan kegiatan utama bank yang mengundang resiko yang dapat berpengaruh pada kesehatan dan kelangsungan usaha bank. Namun mengingat sebagai lembaga intermediasi, sebagian besar dan bank berasal dari dana masyarakat, maka pemberian kredit perbankan banyak dibatasi oleh ketentuan undang - undang dan ketentuan bank indonesia.

\subsubsection{Pencapaian Tujuan}

Pencapaian tujuan adalah keseluruhan upaya pencapaian tujuan harus dipandang sebagai suatu proses. Oleh karena itu, agar pencapaian tujuan akhir semakin terjamin, diperlukan tahapan, baik dalam arti tahapan pencapaian bagian-bagiannya maupun tahapan dalam arti periodisasinya

Program Kredit Usaha Rakyat (KUR) betul-betul sudah berjalan lancar atau efektif dimana para pihak debitur tidak pernah terlambat dalam membayar anggusuran kreditnya jadi bisa dikatakan para debitur usahanya berkembang dengan adanya program KUR.

Calon debitur untuk mendapatkan dana KUR itu harus benar-bemar mempersiapkan syarat-syarat yang dibutuhkan bank untuk mendapatkan dana KUR. Tingkat kepuasan masyarakat terhadap pihak dalam program kredit usaha rakyat (KUR) sangat memuaskan dan membantu para pengusaha kecil yang ingin menggembankan usahanya.

Program Kredit Usaha Rakyat (KUR) ini karena dapat membantu masyarakat dalam meningkatkan kesejahteraan rakyat serta membantu pemerintah dalam pemberdayaan masyarakat itu sendiri. Peran masyarakat sangat berpengaruh juga dalam program ini karena dalam persyaratan pengajuan permohonan KUR harus melampirkan Surat Keterangan Usaha.

Penerima Kredit Usaha Rakyat (KUR) sangat terbantu dengan adanya program ini, karena dapat mengembangakan usaha yang dimilikinya. Disisi lain juga pemerintah memberikan kemudahan dalam proses pengurusan Surat Keterangan Usaha sebagai salah satu persyaratan dalam proses permohonan KUR tersebut.

Berdasarkan hasil, peneliti dapat mengemukakan bahwa dalam proses pencapaian tujuan program Kredit Usaha Rakyat (KUR) ini diperlukan keterkaitan satu sama lain. Program ini hadir sebagai solusi bagi masyarakat yang ingin mengembangkan usahanya namun minim akan dana. Melihat kondisi Negara ini adalah proses adaptasi menuju Negara maju sehingga dibutuhkan penunjang untuk mendukung pencapaian tersebut. Program KUR adalah salah satu program pemerintah yang bekerjasama dengan lembaga penjamin untuk membantu masyarakat dalam peningkatan usaha yang dikelolahnya. Sebagaimana yang disampaikan oleh Sedarmayanti (2009) mengemukakan bahwa konsep efektivitas sebagai suatu ukuran yang memberikan gambaran seberapa jauh target dapat tercapai. Dalam proses pencairan dana Kredit Usaha Rakyat (KUR).

\section{KESIMPULAN}

Berdasarkan hasil penelitian dan pembahasan yang dipaparkan, maka dapat disimpulkan bahwa Pencapaian tujuan program Kredit Usaha Rakyat (KUR) telah tercapai hal ini dapat di buktikan dengan perkembangan usaha masyarakat penerima dana Kredit Usaha Rakyat (KUR). Proses sosialisasi telah dilakukan secara efektif. Hal ini merangsang pertumbuhan usaha skala mikro dan menegah pada masyarakat pasca adanya program dana Kredit Usaha Rakya (KUR). Adaptasi penyaluran dana kredit usaha rakyat (KUR) berdampak pada penggembangan usaha sesuai potensi daerah berupa penambahan alat dan perluasaan pasar untuk nelayan dan penggembangan usaha bagi masyarakat sekitar parawisata.

\section{REFERENCES}

Anggraeni, F. D., Hardjanto, I., \& Hayat, A. (2013). Pengembangan Usaha Mikro, Kecil, Dan Menengah (UMKM) Melalui Fasilitasi Pihak Eksternal Dan Potensi Internal. Jurnal Administrasi Publik, 1(6), 1286-1295.

Anggraini, D., \& Nasution, S. (2013). Peranan Kredit Usaha Rakyat (Kur) Bagi Pengembangan Umkm Di Kota Medan (Studi Kasus Bank Bri). Jurnal Ekonomi Dan Keuangan, 1(3), 14879.

Antara, I. K. A., \& Luh Putu Aswitari. (2016). BEBERAPA FAKTOR YANG MEMPENGARUHI PENDAPATAN PEDAGANG KAKI LIMA DI KECAMATAN DENPASAR BARAT. E-Jurnal Ekonomi Pembangunan Universitas Udayana, 05(11), 12651291.

Erlina, H. (2014). ANALISIS PENGARUH PEMBERIAN KREDIT USAHA RAKYAT (KUR) TERHADAP KINERJA USAHA KECIL DI KOTA MAKASSAR (Studi Kasus PT. Bank Rakyat Indonesia (Persero) Tbk Cabang A. Yani Makassar). Universitas Hasanuddin.

Fransiska, P. (2016). ANALISIS KELAYAKAN KREDIT DITINJAU DARI ASPEK KEUANGAN PADA PT. BANK MUAMALLAT 
INDONESIA TBK

HAOJAHAN, J. B. (2014). EFEKTIVITAS PROGRAM KREDIT USAHA RAKYAT(KUR) DALAM MENINGKATKAN KESEJAHTERAAN MASYARAKAT OLEH BANK RAKYAT INDONESIA (BRI) DI KELURAHAN HARJOSARI KEC MEDAN AMPLAS. UNIVERSITAS SUMATERA UTARA MEDAN

INDONESIA, G. B. (2003). PEMBERIAN BANTUAN TEKNIS DALAM RANGKA PENGEMBANGAN USAHA MIKRO DAN KECIL. In PERATURAN BANK INDONESIA.

Jusuf, J. (2014). Analisis Kredit Untuk Account Officer. PT. Gramedia Pustaka Utama.

Lastina, N. luh made A. danni, \& Budhi, M. K. S. (2018). Efektivitas Penyaluran Kredit Usaha Rakyat Pt. Bri (Persero) Unit Blahkiuh Terhadap Produktivitas Ukm Dan Pendapatan Ukm Penerima Kur Di Kecamatan Abiansemal. E-Jurnal Ekonomi Dan Bisnis Universitas Udayana, 4, 959. https://doi.org/10.24843/eeb.2018.v07.i04.p02

Putra, I. G. A. A. S., \& Saskara, I. A. N. (2013). Efektivitas dan dampak program bantuan kredit usaha rakyat (KUR) terhadap pendapatan dan kesempatan kerja usaha mikro kecil dan menengah (UMKM) di Kota Denpasar. E-Jurnal EP Unud, 2(10), 457468.

Ramayanti, A. (2018). Upaya Pemerintah Dalam Pengembangan Usaha Mikro Kecil dan Menengah (UMKM) Di Kabupaten Tapanuli Selatan (Studi Kasus Tenun Sipirok). Universitas Muhammadiyah Sumatera Utara.

Siagian, M., Kurniawan, P. H., \& Hikmah, H. (2019). Analisis Faktor Eksternal Dan Internal Terhadap Kinerja Umkm Di Kota Batam. Jesya (Jurnal Ekonomi \& Ekonomi Syariah), 2(2), 265-271. https://doi.org/10.36778/jesya.v2i2.107

SUGIANTI, S. (2019). PERAN USAHA MIKRO KECIL DAN MENENGAH (UMKM) DALAM MENSEJAHTERAKAN KARYAWAN DI PUSAT OLEH-OLEH MAK DENOK DESA SERDANG JAYA KABUPATEN TANJUNG JABUNG BARAT. UNIVERSITAS ISLAM NEGERISULTHAN THAHA SAIFUDDIN JAMBI.

Wahyuni, E. P. (2016). EFEKTIVITAS PENGGUNAAN APLIKASI OA (OFFICE AUTOMATION) BAGI KARYAWAN PT PLN (PERSERO) WS2JB AREA PALEMBANG DALAM KEGIATAN PENGELOLAAN SURAT-MENYURAT. Politeknik Negeri Sriwijaya.

Widyaresti, E. P., \& Setiawan, A. H. (2012). Analisis Peran Bri Unit Ketandan Dalam Pemberian Di Kecamatn Ngawen Kabupaten Klaten. DIPONEGORO JOURNAL OF ECONOMICS, 1(1), 1-11.

Wijayanto, A. (2013). Pengaruh Karakteristik Wirausahawan Terhadap Tingkat Keberhasilan Usahan. Jurnal Ilmu Sosial, 12(1), 1628. 